\title{
Hydrologic Simulation of a Winter Wheat-Summer Maize Cropping System in an Irrigation District of the Lower Yellow River Basin, China
}

\author{
Lei Liu ${ }^{1}$, Jianqin Ma ${ }^{1, *}$, Yi Luo ${ }^{2}$, Chansheng He ${ }^{3,4}$ and Tiegang Liu 5 \\ 1 North China University of Water Resources and Electric Power, No. 36 Beihuan RD., Zhengzhou 450011, \\ China; liuleiacid@126.com \\ 2 The Key Laboratory of Ecological Network Observation and Modeling, Institute of Geographic Sciences and \\ Natural Resources Research, Chinese Academy of Sciences (CAS), 11A Datun RD., Beijing 100101, China; \\ luoyi1966@yeah.net \\ 3 Center for Dryland Water Resources Research and Watershed Science, Key Laboratory of West China's \\ Environmental System (Ministry of Education), Lanzhou University, Lanzhou 730000, China \\ 4 Department of Geography, Western Michigan University, Kalamazoo, MI 49008, USA; \\ chansheng.he@wmich.edu \\ 5 State Key Laboratory of Hydraulics and Mountain River Engineering, College of Water Resource \& \\ Hydropower, Sichuan University, Chengdu 610065, China; liutiegang79@163.com \\ * Correspondence: majianqin@ncwu.edu.cn; Tel.: +86-371-8654-9227
}

Academic Editor: Y. Jun Xu

Received: 30 June 2016; Accepted: 17 December 2016; Published: 1 January 2017

\begin{abstract}
Conflicts between water supply and water demand are intensifying in irrigation districts along the Lower Yellow River due to climate change and human activities. To ensure both adequate food supply and water resource sustainability in China, the Soil and Water Assessment Tool (SWAT) model was used to simulate the water balance and water use of agro-ecosystems in an irrigation district of the lower Yellow River Basin, China. Simulated average annual irrigation requirements decreased from 1969 to 2010. Irrigation requirements during the winter wheat season decreased owing to reduced reference evapotranspiration and increased precipitation. Annual evapotranspiration (ET) increased with increasing irrigation volume, and differences among irrigation scenarios were mainly due to ET of winter wheat. Water deficit typically occurred during winter wheat seasons with less precipitation. Field seepage and surface runoff tended to occur in years with high precipitation, particularly during the summer maize season under full irrigation and scheduled irrigation scenarios. Frequent and heavy irrigation did not always lead to high water use efficiency. To cope with limited water resources in this region, it is necessary to properly irrigate crops based on soil water content and take full advantage of precipitation and surface runoff during the summer maize season.
\end{abstract}

Keywords: water balance; evapotranspiration; irrigation district; Soil and Water Assessment Tool

\section{Introduction}

Irrigation districts along the lower reaches of the Yellow River are primary grain production regions in China. In 2000, total grain production in the lower Yellow River Basin was $3.583 \times 10^{7} \mathrm{t}$, which accounted for about 7.8\% of China's total grain production. Water from the Yellow River is a main source for irrigation in the lower Yellow River Basin. However, under the influence of climate change and human activities, irrigation districts are facing serious shortages in the amount of water available from the Yellow River, further intensifying conflicts between water supply and water demand. Thus, understanding the water cycle and water use in this important agricultural ecosystem is critical for ensuring adequate food supply and water resource sustainability in China. 
A number of watershed models, such as AGNPS (Agricultural Non-point Source Pollution Model [1]), EPIC (Erosion Productivity Impact Calculator [2]), and SWAT (Soil and Water Assessment Tool [3]), have been developed to analyze water resources in agricultural watersheds. AGNPS is a non-point-source pollution model for evaluating agricultural watersheds, EPIC predicts the impact of erosion on soil productivity, and SWAT incorporates hydrological, chemical, and ecological processes and management practices into watershed simulations. The SWAT model also simulates physical processes, such as hydrology, soil-water interactions, and crop growth on a daily basis and estimates plant growth with a simplified generic crop growth module from the EPIC plant growth model [4]. Crop evapotranspiration (ET) is an important component of the water cycle in agricultural watersheds. SWAT2000 analyzes the effects of crops on the hydrological process by integrating the EPIC plant growth model into its framework. As Luo et al. [5] modified the SWAT2000 and Liu et al. [6] have applied it to analyze the water balance of irrigation districts in the Lower Yellow River Basin, in this paper, the modified SWAT2000 model is used to simulate crop growth processes and water balance at the field scale.

As a physically-based distributed hydrological model, SWAT has been used to simulate water cycles of watersheds, as well as the impacts of human activities on watershed processes and agricultural production [5,7-12]. In most cases, parameterization of the SWAT model and many other watershed-scale hydrological models has been performed based on stream flow data at the outlet of the study watershed or subwatershed [7-10,13-16]. Parameterization is performed either manually, through 'trial and error', or automatically with optimization programs, such as SCE (Shuffled Complex Evolution) [17,18]. Distributed parameters are calibrated and verified with a lumped approach. Recently, however, there have been attempts to parameterize distributed watershed models with remote sensing data of spatially-distributed vegetation biomass, leaf area index (LAI), ET, and soil evaporation [19-21].

In some cases, parameterization of hydrologic models is challenged by scarcity of stream-flow data, especially in areas without well-defined watershed boundaries. Alternative calibration techniques must be used for these cases. For example, Santhi et al. [22] used crop ET and canal conveyance efficiency to calibrate SWAT for assessing the irrigation demand of irrigation districts in the lower Rio Grande Valley in Texas. Luo et al. [5] used crop growth and yield at the field scale in this region to test the variability and transferability of SWAT.

Winter wheat, summer maize, and soybean are the main crops grown in the Lower Yellow River Basin. In 2000, the planting area of winter wheat and summer maize accounted for $37.4 \%$ and $18.6 \%$ of the total planting area, respectively. Winter wheat-summer maize is the primary cropping system in this region. Winter wheat rotated with soybean or other legume crops are also adopted but are not very common. Thus, to better understand water balance in the study area, we simulated water balance of a winter wheat-summer maize cropping system with SWAT2000. Due to the lack of availability of runoff data in agricultural areas, SWAT2000 was calibrated and validated based on soil profile parameters and crop growth parameters in the study area. Luo et al. [5] assessed the winter wheat growth and soil water modules of SWAT2000 using field data from the Yucheng Comprehensive Experimental Station (YCES), which is located in the study area. Following the approach of Luo et al. [5], Liu et al. [6] developed a new combined irrigation, drainage, and storage (CIDS) module for SWAT2000 and calibrated and validated growth and soil water processes of summer maize based on field data. However, inadequacies in summer maize growth simulations should be further analyzed.

The goals of this study were to (1) analyze the causes of inadequacies in summer maize growth simulations; (2) design different scenarios to study the effects of different irrigation schemes and climate variability on the water cycle and water use of a winter wheat-summer maize cropping system at the field scale under the assumption of no nutrient stress; and (3) evaluate the main causes of annual variation in hydrological process of the winter wheat-summer maize cropping system. 


\section{Materials and Methods}

\subsection{The Study Area}

A field experiment was conducted at YCES $\left(36^{\circ} 56^{\prime} \mathrm{N}, 116^{\circ} 36^{\prime} \mathrm{E}\right)$ of the Chinese Academy of Sciences in Yucheng City, Shandong Province, China. YCES is located in the Panzhuang Irrigation District in the fluvial plain of the Yellow River, Hai River, and Huai River, known as the Huang (Yellow)-Huai-Hai Plain (Figure 1). The mean annual precipitation is about $600 \mathrm{~mm}$, ranging from $238 \mathrm{~mm}$ to $1142 \mathrm{~mm}$, and about 70\% of the precipitation falls during June to September. The annual mean temperature is $13.5^{\circ} \mathrm{C}$, ranging from $12.1^{\circ} \mathrm{C}$ to $15.3^{\circ} \mathrm{C}$. The maximum monthly temperature is $27.0^{\circ} \mathrm{C}$, occurring in July, and the minimum is $-2.2{ }^{\circ} \mathrm{C}$, occurring in January.

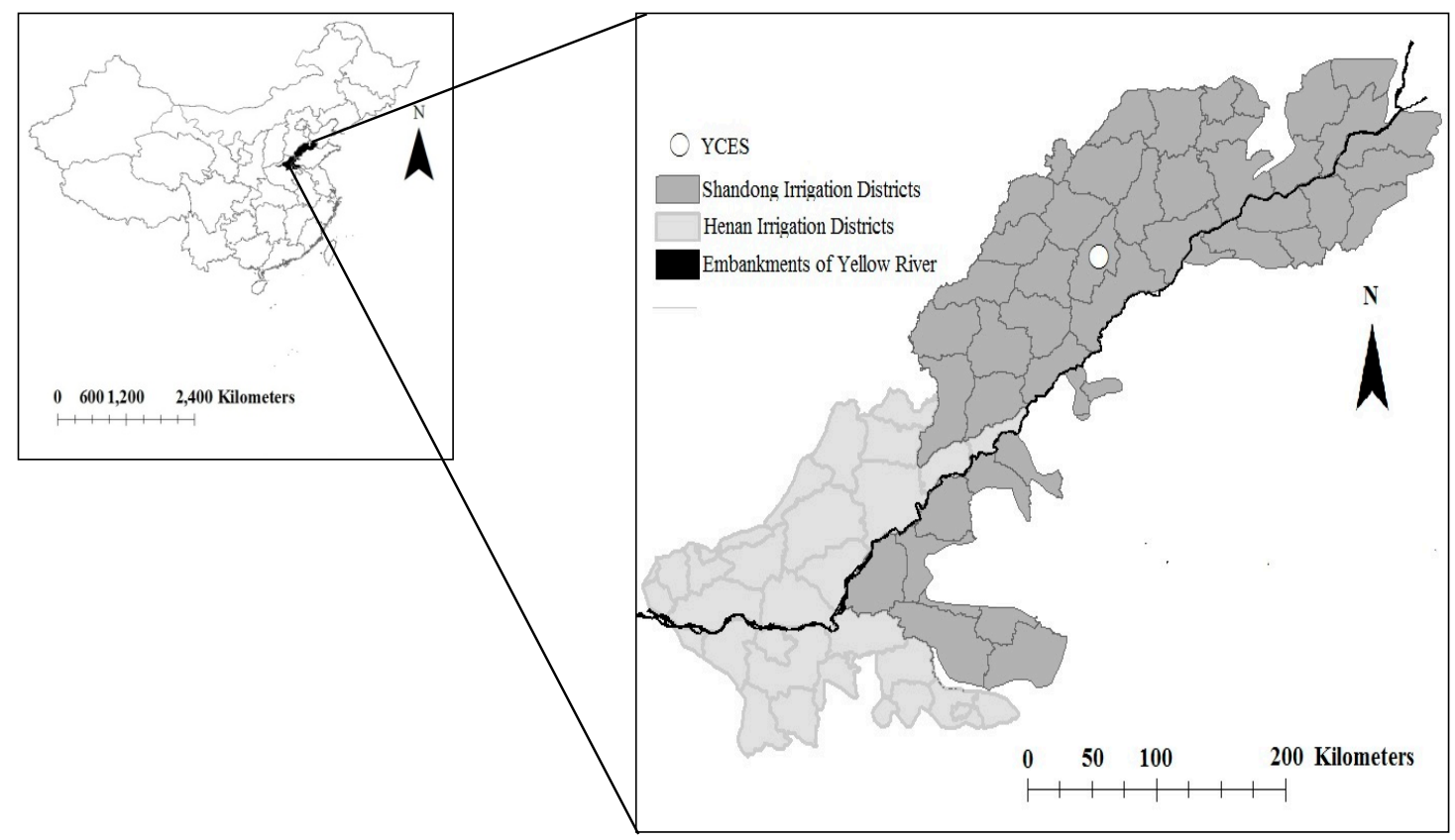

Figure 1. Study area along the lower reach of the Yellow River. YCES is the location of 32 experimental plots.

Winter wheat and summer maize experiments were carried out on 32 experimental plots (Figure 2). All plots had an area of $5 \times 10 \mathrm{~m}^{2}$ and were divided into four rows named $\mathrm{A}, \mathrm{B}, \mathrm{C}$, and D. Concrete barriers ( $0.1 \mathrm{~m}$ thick, $1 \mathrm{~m}$ deep (below the ground), and $0.1 \mathrm{~m}$ high (above the ground)) were constructed around each plot to block lateral flow among the plots.

\begin{tabular}{|l|l|l|l|l|l|l|l|}
\hline \hline D8 & D7 & D6 & D5 & D4 & D3 & D2 & D1 \\
\hline C8 & C7 & C6 & C5 & C4 & C3 & C2 & C1 \\
\hline \hline B8 & B7 & B6 & B5 & B4 & B3 & B2 & B1 \\
\hline
\end{tabular}

\begin{tabular}{|l|l|l|l|l|l|l|l|}
\hline \hline A8 & A7 & A6 & A5 & A4 & A3 & A2 & A1 \\
\hline
\end{tabular}

Figure 2. Layout of winter wheat and summer maize experimental plots. 
Both experiments included eight treatments, each with four replicates (Tables 1 and 2). Precipitation during the winter wheat growing season typically does not satisfy the water requirements of winter wheat. Therefore, to reflect the water consumption of winter wheat under different water supply levels, the eight treatments were set as combinations of four water supply levels: no irrigation (A1-A4, C1-C4), 40\% of field capacity (FC) (A5-A8, C5-C8), 60\% FC (B1-B4, D1-D4), and 80\% FC (B5-B8, D5-D8), and two planting densities: normal density (ND) (A1-A8, B1-B8) and 25\% ND (C1-C8, D1-D8). During the summer maize growing season, precipitation can meet the water demand of summer maize, except during drought years, but different planting densities largely impact summer maize water consumption. Thus, the eight treatments were set as combinations of four planting densities: 150\% ND (A1-A8), 133\% ND (B1-B8), 117\% ND (C1-C8), and ND (D1-D8), and two water supply levels: no irrigation (A1-A4, B1-B4, C1-C4, D1-D4) and 60\% FC (A5-A8, B5-B8, C5-C8, D5-D8). As an example, $60 \%$ FC means when the soil water storage in the top $60 \mathrm{~cm}$ soil layer was less than $60 \%$ of FC, irrigation was applied to fill the $60 \mathrm{~cm}$ soil layer to field capacity.

Table 1. Winter wheat plot arrangement and irrigation treatments [5].

\begin{tabular}{|c|c|c|c|c|c|c|c|c|c|}
\hline & 1 & 2 & 3 & 4 & 5 & 6 & 7 & 8 & Plant Density \\
\hline A & \multirow{2}{*}{\multicolumn{4}{|c|}{$\begin{array}{l}\text { Treatment I: No irrigation } \\
\text { Treatment III: } 60 \% \text { FC }\end{array}$}} & \multicolumn{4}{|c|}{ Treatment II: $40 \%$ FC } & \multirow{2}{*}{ ND } \\
\hline B & & & & & & me & 80 & & \\
\hline $\mathrm{C}$ & \multicolumn{4}{|c|}{ Treatment V: No irrigation } & & \multicolumn{2}{|c|}{ Treatment VI: 40\% FC } & & \multirow{2}{*}{$75 \%$ ND } \\
\hline $\mathrm{D}$ & \multicolumn{4}{|c|}{ Treatment VII: 60\% FC } & \multicolumn{4}{|c|}{ Treatment VIII: 80\% FC } & \\
\hline
\end{tabular}

Table 2. Summer maize plot arrangement and irrigation treatments.

\begin{tabular}{|c|c|c|c|c|c|c|c|c|c|}
\hline & 1 & 2 & 3 & 4 & 5 & 6 & 7 & 8 & Plant Density \\
\hline A & \multicolumn{4}{|c|}{ Treatment I: No irrigation } & \multicolumn{4}{|c|}{ Treatment II: $60 \%$ FC } & $150 \%$ ND \\
\hline B & \multicolumn{4}{|c|}{ Treatment III: No irrigation } & \multicolumn{4}{|c|}{ Treatment IV: $60 \%$ FC } & $133 \% \mathrm{ND}$ \\
\hline $\mathrm{C}$ & \multicolumn{4}{|c|}{ Treatment V: No irrigation } & \multicolumn{4}{|c|}{ Treatment VI: 60\% FC } & $117 \%$ ND \\
\hline $\mathrm{D}$ & \multicolumn{4}{|c|}{ Treatment VII: No irrigation } & \multicolumn{4}{|c|}{ Treatment VIII: $60 \%$ FC } & ND \\
\hline
\end{tabular}

Soil water content was measured from the surface to a depth of $1.5-2.0 \mathrm{~m}$ at $0.1 \mathrm{~m}$ increments once a week with neutron probe access tubes. According to the measured soil water content, each plot was irrigated based on its assigned irrigation treatment. Crop growth observations including LAI and biomass were observed once a week, and yield was measured at harvest. Daily crop ET was measured with a weighing lysimeter.

\subsection{Data Preparation}

\subsubsection{Weather}

Weather data used in this study were acquired from a meteorological station in Yucheng, where YCES is located. The daily meteorological datasets from 1961 to 2010 included maximum and minimum temperature $\left({ }^{\circ} \mathrm{C}\right)$, wind speed at $10.0 \mathrm{~m}\left(\mathrm{~m} \cdot \mathrm{s}^{-1}\right)$, relative humidity $(\%)$, precipitation $(\mathrm{mm})$, and sunshine hours (h). The Penman-Monteith formula embedded in the SWAT2000 model was used to estimate daily ET.

The quality of meteorological data was examined and no apparent errors were found. Missing daily data accounted for about $1.65 \%$ of each meteorological parameter's total data. In our simulations, these missing data were generated with the WXGEN weather generator model included in the SWAT2000 model. 


\subsubsection{Crop Parameters}

The winter wheat growing season is approximately 240 days, and the summer maize growing season is approximately 102 days. Winter wheat is usually planted in early or middle October and harvested in early June of the following year; summer maize is usually planted in early or middle June and harvested in early October. Initial values of some important shape coefficients for LAI curves such as BLAI (maximum potential leaf area index), FRGRW1 (fraction of the plant growing season or fraction of total potential heat units corresponding to the 1st point on the optimal leaf area development curve), LAIMX1 (fraction of the maximum leaf area index corresponding to the first point on the optimal leaf area development curve), FRGRW2 (fraction of the plant growing season or fraction of total potential heat units corresponding to the second point on the optimal leaf area development curve), LAIMX2 (fraction of the maximum leaf area index corresponding to the second point on the optimal leaf area development curve), and DLAI (fraction of growing season when leaf area declines) were obtained from the default crop database in SWAT2000 [4]. Observational data for LAI and biomass of crops in YCES were used to refine the LAI shape coefficients. LAI parameters for winter wheat and summer maize in the simulation were derived from Luo et al. [5] and Liu et al. [6], respectively (Table 3$)$.

Table 3. LAI parameters for winter wheat and summer maize used in the simulation.

\begin{tabular}{cccccccc}
\hline Growth Season & $\mathbf{P H U}\left({ }^{\circ} \mathbf{C}\right)^{\mathbf{a}}$ & $\mathbf{L A I}_{\mathbf{m a x}} \mathbf{b}$ & $\mathbf{f r}_{\mathbf{p h u}, \mathbf{1}} \mathbf{c}$ & $\mathbf{f r}_{\text {lai, } \mathbf{1}} \mathbf{d}$ & $\mathbf{f r}_{\mathbf{p h u , 2}} \mathbf{e}$ & $\mathbf{f r}_{\text {lai,2 }} \mathbf{f}$ & $\mathbf{f r}_{\mathbf{p h u , s e n}} \mathbf{g}$ \\
\hline Winter wheat & 1852.6 & 8.5 & 0.20 & 0.20 & 0.45 & 0.96 \\
Summer maize & 1850.9 & 5.0 & 0.35 & 0.30 & 0.50 & 0.48 \\
\hline
\end{tabular}

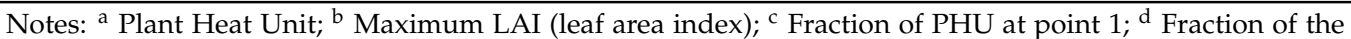
maximum LAI at point $1 ;{ }^{\mathrm{e}}$ Fraction of PHU at point 2; ${ }^{\mathrm{f}}$ Fraction of the maximum LAI at point 2; ${ }^{\mathrm{g}}$ Fraction of PHU when senescence dominates leaf development.

\subsubsection{Soil Data}

The soil texture was mainly silt loam, and relevant soil parameters, such as bulk density, soil available water content, saturated hydraulic conductivity, organic carbon content, clay content, silt content, and sand content for each soil layer were taken from Luo et al. [5] (Table 4).

Table 4. Soil parameters used in the simulation [5].

\begin{tabular}{cccccccc}
\hline Depth $(\mathbf{m m})$ & $\mathbf{5 0 . 0}$ & $\mathbf{3 0 0 . 0}$ & $\mathbf{6 0 0 . 0}$ & $\mathbf{7 0 0 . 0}$ & $\mathbf{8 0 0 . 0}$ & $\mathbf{1 2 0 0 . 0}$ & $\mathbf{1 8 0 0 . 0}$ \\
\hline Bulk density $\left(\mathrm{g} / \mathrm{cm}^{3}\right)$ & 1.45 & 1.50 & 1.46 & 1.50 & 1.45 & 1.45 & 1.45 \\
Soil AWC $^{\text {a }}(\mathrm{mm} / \mathrm{mm})$ & 0.26 & 0.26 & 0.24 & 0.24 & 0.22 & 0.22 & 0.22 \\
$\mathrm{~K}_{\text {sat }}$ b $(\mathrm{mm} / \mathrm{h})$ & 150.0 & 150.0 & 150.0 & 150.0 & 150.0 & 150.0 & 150.0 \\
Content of organic carbon $(\%)_{\text {Content of clay (\%) }}^{2.5}$ & 1.0 & 0.0 & 0.0 & 0.0 & 0.0 & 0.0 \\
Content of silt (\%) & 11.8 & 18.8 & 18.5 & 18.5 & 19.5 & 14.0 & 15.7 \\
Content of sand (\%) & 66.7 & 67.8 & 70.6 & 70.6 & 70.6 & 70.6 & 70.6 \\
\hline
\end{tabular}

Notes: ${ }^{a}$ AWC: available water content; ${ }^{\text {b }}$ saturated hydraulic conductivity.

\subsubsection{SWAT Model Configuration}

A modified SWAT2000 model (parameterized by Liu et al. [6]) was employed to simulate the water balance of a winter wheat-summer maize cropping system at the field scale based on 32 experimental plots in YCES. Plots with the same planting density of summer maize were considered as virtual subbasins, leading to four subbasins in total. Plots in each subbasin were considered as hydrological response units (HRUs), and each subbasin had eight HRUs. For SWAT2000 simulations, separate management files were written for each HRU or group of HRUs with the same operation practices. 


\subsection{Model Limitations in Simulating Crop Growth}

The parameters used to calibrate and validate SWAT included soil water, LAI, biomass, and crop ET. All of these parameters were adopted from Luo et al. [5] and Liu et al. [6]. However, due to the data availability, the model parameters used have not been validated with a series of independent data. According to the above two studies, these parameters were calibrated and validated during winter wheat and summer maize seasons with observed crop LAI and biomass, soil water storage in the upper $60 \mathrm{~cm}$, and crop ET at YCES. These two studies reported strong performance of SWAT2000 simulations of LAI, biomass, and soil water moisture during different crop growing seasons.

Luo et al. [5] reported that SWAT2000 performed well in LAI, biomass, and soil water moisture simulations during the winter wheat season. However, LAI during the senescence stage was overestimated because it was modeled without considering water stress. Moreover, crop yield was overestimated due to improper computation of the harvest index and soil water storage was underestimated under dry conditions due to the exclusion of groundwater evaporation from the soil water balance in SWAT.

Liu et al. [6] showed that SWAT2000 performed well in simulating LAI and biomass of summer maize without showing the simulation inadequacies. However, SWAT2000 cannot accurately simulate summer maize leaf development during leaf senescence. In the SWAT growth module, the development of LAI is affected by plant heat units (PHU) and is assumed to be unrelated to environmental factors such as water, temperature, nitrogen, and phosphorus. In reality, environmental factors can influence both leaf growth and leaf senescence [23], as senescence of maize leaves is a complex process regulated by both internal and external factors, such as $\mathrm{N}$ uptake and light [24]. SWAT's failure to consider the effects of water stress on leaf growth after maximum LAI may lead to unsatisfactory prediction of winter wheat LAI after senescence [5]. Water stress did not have a strong impact on summer maize growth, as soil water was sufficient during senescence in 2004 and 2005. However, summer maize growth during senescence may still be affected by several factors such as temperature, light, $\mathrm{N}$, and $\mathrm{P}$, and inadequate consideration of these factors in the SWAT model may result in unsatisfactory simulations.

When applied to our field experiments, SWAT2000 underestimated summer maize yield and Liu et al. [6] did not report this. Observed yield was quite different for each plot in 2004 and 2005. The average observed yield was $7925 \pm 763 \mathrm{~kg} / \mathrm{ha}$ in 2004 and $7229 \pm 1218 \mathrm{~kg} / \mathrm{ha}$ in 2005. In contrast, the simulated summer maize yield was similar among the 32 plots, and average simulated yield was $7165 \mathrm{~kg} / \mathrm{ha}$ in 2004 and $6968 \mathrm{~kg} / \mathrm{ha} \pm 127 \mathrm{~kg} / \mathrm{ha}$ in 2005. Table 5 shows the average relative error between simulated and observed yield in 2004 and 2005. Maize yield is affected by environmental factors, such as rainfall, temperature, soil water, nutrient supply, sowing time, and planting density [25-27]. As nutrient supply, sowing time, and meteorological conditions were the same during the summer maize experiment, planting density may be the main factor causing variation in observed yield among the different treatments. Inadequate representation of planting density in the SWAT model may have resulted in inaccurate yield simulation. Poor agreement between simulated and observed maize yield may also be a result of the EPIC model for crop yield, which has shown poor results in previous yield predictions [5].

Table 5. Average relative error between simulated and observed summer maize yield (\%).

\begin{tabular}{ccccccccc}
\hline Growth Season & A1-A4 & A5-A8 & B1-B4 & B5-B8 & C1-C4 & C5-C8 & D1-D4 & D5-D8 \\
\hline 2004 & -22.7 & -19.9 & -18.7 & -20.4 & -25.4 & -19 & -10.3 & -1.6 \\
2005 & -1.1 & -8.1 & -18.7 & -22.6 & -18.3 & -15.5 & -1.7 & 10.4 \\
\hline
\end{tabular}

Environmental conditions can cause large inter-annual variation in summer maize growth, and a variety of environmental factors influence phenological development and relevant growth processes (e.g., temperature). Base or minimum temperature $\left(T_{\min }\right)$, optimum temperature $\left(T_{\text {opt }}\right)$ and maximum 
temperature $\left(\mathrm{T}_{\max }\right)$ are all important for calculating phonological parameters [28-30]. At our study site, maximum and minimum temperatures varied between 2004 and 2005, particularly during initial stages of the summer maize season (Figure 3). The fraction of PHU and maximum LAI at point 1, the fraction of PHU at point 2, and the fractions of PHU during senescence differed significantly between 2004 and 2005 (Table 6). Soil water can also affect the phenological development of maize. Soil water was abundant in 2004, and summer maize did not experience water stress during this time (Figure 4). For plot B4, the soil water level in the top $60 \mathrm{~cm}$ of soil was about $204 \mathrm{~mm}$ during the summer maize season in 2004 and $160 \mathrm{~mm}$ in 2005, and summer maize development was quicker in 2004 with more soil water (Table 6).

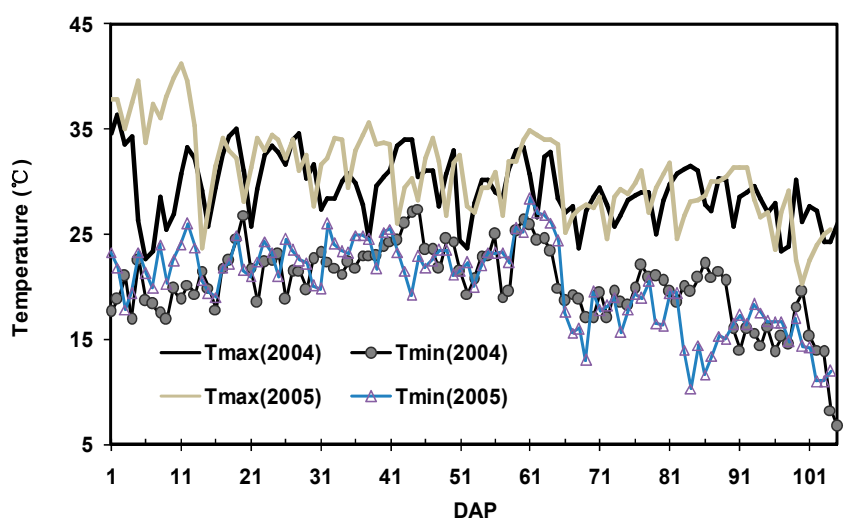

Figure 3. Maximum and minimum temperature during the summer maize season in 2004 and 2005.

Tmax: maximum temperature; Tmin: minimum temperature; and DAP: days after planting.
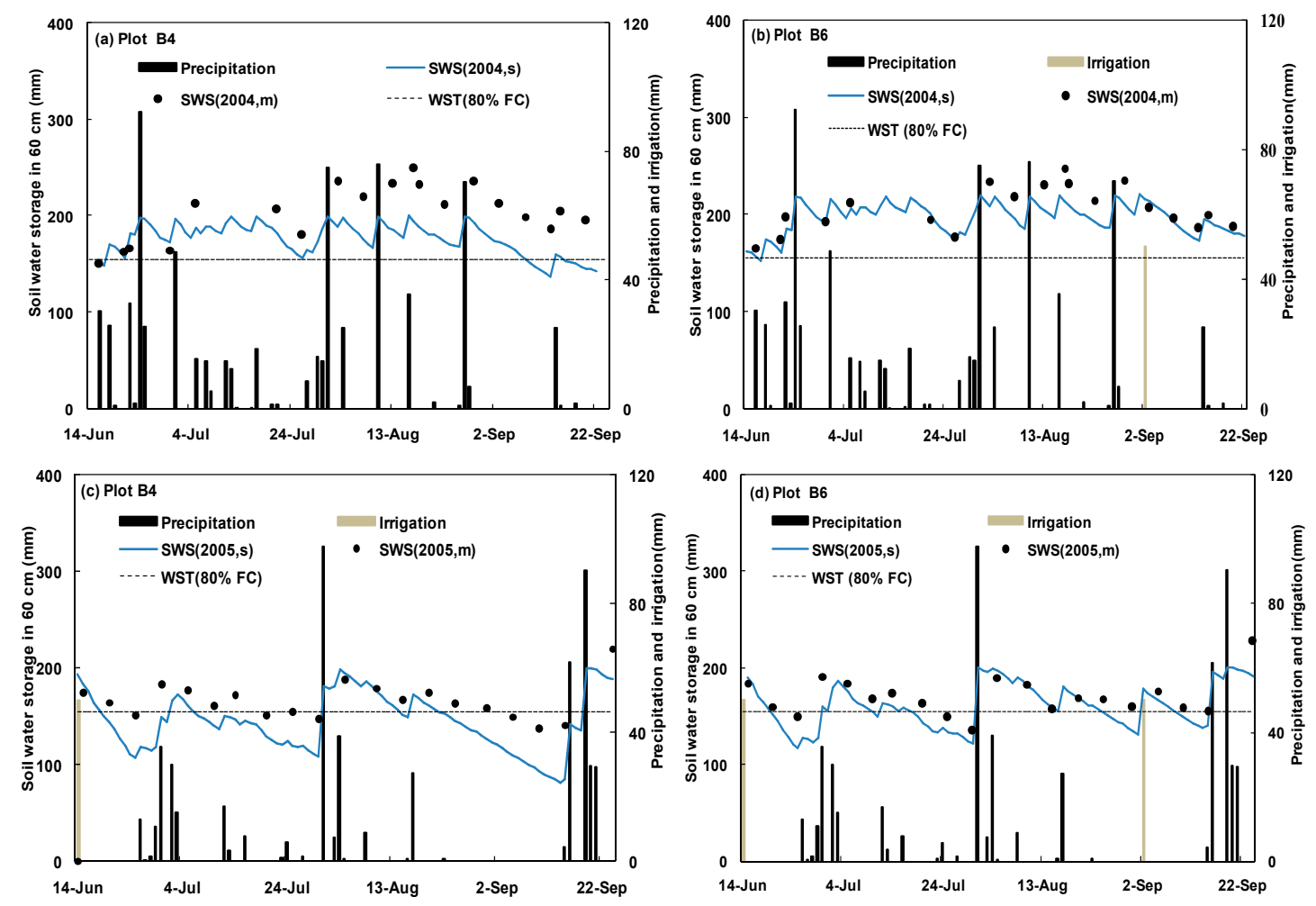

Figure 4. Comparison of simulated and measured soil water storage in the upper $60 \mathrm{~cm}$ during the summer maize season in 2004 and 2005. (a) Plot B4 in 2004; (b) Plot B6 in 2004; (c) Plot B4 in 2005; and (d) Plot B6 in 2005. SWS: soil water storage; s: simulated value, m: measured value; and WST: water stress threshold. 
Table 6. LAI parameters of summer maize.

\begin{tabular}{cccccccc}
\hline Growth Season & $\mathbf{P H U}\left({ }^{\circ} \mathbf{C}\right)^{\mathbf{a}}$ & $\mathbf{L A I}_{\text {max }} \mathbf{b}$ & $\mathbf{f r}_{\mathbf{p h u}, \mathbf{1}}{ }^{\mathbf{c}}$ & $\mathbf{f r}_{\text {lai, } \mathbf{1}} \mathbf{d}$ & $\mathbf{f r}_{\mathbf{p h u , 2}} \mathbf{e}$ & $\mathbf{f r}_{\text {lai, } \mathbf{2}}{ }^{\mathbf{f}}$ & $\mathbf{f r}_{\mathbf{p h u , s e n}} \mathbf{g}$ \\
\hline 2004 & 1750.4 & 5 & 0.25 & 0.27 & 0.40 & 0.95 & 0.55 \\
2005 & 1870.4 & 5 & 0.37 & 0.30 & 0.55 & 0.95 & 0.65 \\
\hline
\end{tabular}

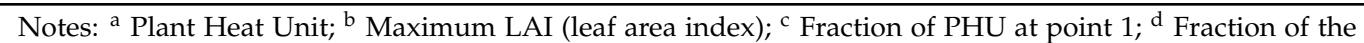
maximum LAI at point 1; ${ }^{\mathrm{e}}$ Fraction of PHU at point 2; ${ }^{\mathrm{f}}$ Fraction of the maximum LAI at point 2; ${ }^{\mathrm{g}}$ Fraction of PHU when senescence dominates leaf development.

\subsection{Scenario Simulations}

Three scenarios were designed to investigate how irrigation regimes and climatic variability influence the water cycle and water use of a winter wheat-summer maize cropping system from 1961 to 2010 .

Scenario 1: Full irrigation (i.e., automatic irrigation in the SWAT2000 model). Crops are irrigated as soon as soil water stress is experienced. Optimal yield occurs once the soil water content reaches $80 \%$ FC, and yield will decline if the soil water content exceeds $80 \%$ FC [31]. Thus, the soil water stress threshold is defined as $80 \%$ FC [32-34]. In this study, we assumed that winter wheat and summer maize were irrigated automatically when the soil water content in the top $60 \mathrm{~cm}$ of soil was less than $80 \%$ FC.

Scenario 2: Scheduled irrigation. According to amount of water applied in Scenario 1 and the frequency of water stress under no irrigation, the irrigation level for winter wheat was about $60 \mathrm{~mm}$ per irrigation event. Farmers usually water winter wheat from the jointing to milking stage. Field studies have reported irrigation levels ranging from 60 to $105 \mathrm{~mm}$ per event [35-37]. Thus, winter wheat was irrigated $(60 \mathrm{~mm})$ three times: 15 March, 15 April, and 15 May.

Non-irrigated summer maize experienced serious water stress twice as often as irrigated crops (with $60 \mathrm{~mm}$ of water per application). Depending on rainfall, summer maize typically is irrigated 1 to 2 times per growing season and may even receive no irrigation in wetter years. Previous field studies have reported summer maize irrigation levels ranging from 45 to $105 \mathrm{~mm}$ per event [36-38]. Therefore, in this scenario, summer maize was irrigated once with $45 \mathrm{~mm}$ of water on 12 June.

Scenario 3: No irrigation for all crops in the study area.

A Mann-Kendall test $[39,40]$ was conducted to analyze trends in climatic series and hydrological variables under different irrigation schemes. Sen's slope estimator [41], $\beta$, which is closely related to the Mann-Kendall test, was used to determine the magnitude of trends.

\section{Results}

\subsection{Irrigation}

Annual variation in irrigation amount was analyzed from 1969 to 2010 to allow an eight-year acclimation period. A comparison of the amount of water used for irrigation each year under Scenarios 1 and 2 is presented in Figure 5. In Scenario 1, the average annual total irrigation was $421 \mathrm{~mm}$, ranging from 147 to $638 \mathrm{~mm}$. The amount of water used for irrigation was influenced by crop water demand and precipitation. There was a negative relationship between precipitation and total irrigation $(\mathrm{r}=-0.65$, $p<0.01$ under Scenario 1). Precipitation can alleviate crop water stress when it occurs in time; otherwise, supplemental irrigation should be practiced. In 1989, precipitation was only $391 \mathrm{~mm}$ (annual precipitation frequency was 90\%), and the irrigation amount was $638 \mathrm{~mm}$. In 2009, when annual precipitation was $819 \mathrm{~mm}$ (annual precipitation frequency was 10\%), the irrigation was $147 \mathrm{~mm}$. In Scenario 2, the average annual irrigation was $225 \mathrm{~mm}$, and this amount remained almost the same each year for predefined irrigation dates and amounts.

The average annual irrigation amount under Scenario 1 significantly decreased from 1969 to 2010 $(p<0.01)$. According to Sen's slope estimator $(\beta)$, the magnitude of the trend was $38 \mathrm{~mm} \cdot$ decade $^{-1}$ (Table 7). During the winter wheat season, irrigation amount decreased significantly with a 
magnitude of $29.1 \mathrm{~mm} \cdot$ decade $^{-1}$; during the summer maize season it decreased with a magnitude of $3.3 \mathrm{~mm} \cdot$ decade $^{-1}$, but the trend was not significant. Thus, the average annual trend was driven by irrigation reductions during the winter wheat season.

Annual variation in irrigation was large (coefficient of variation $C V=0.28$ ) under Scenario 1 . The average annual irrigation amount during the winter wheat season was $307 \mathrm{~mm}$ (Figure 6a), ranging from 174 to $442 \mathrm{~mm}(\mathrm{CV}=0.22)$, and precipitation during the winter wheat season $(152 \mathrm{~mm})$ could not meet crop water demands. The average annual irrigation amount during the summer maize season was $114 \mathrm{~mm}$ (Figure 6b), ranging from 0 to $253 \mathrm{~mm}(\mathrm{CV}=0.67)$. Variation during the summer maize season was greater than that during the winter wheat season because precipitation during the former (388 mm) met crop water demands most years, except during drought years. Furthermore, the average irrigation amount for winter wheat accounted for $73 \%$ of the total annual irrigation amount whereas the percentage for summer maize was only $27 \%$. Therefore, the high CV for annual irrigation under Scenario 1 may largely be due to high annual variation in irrigation during the winter wheat season, though the CV for annual average irrigation amount during the winter wheat season was less than that during the summer maize season.

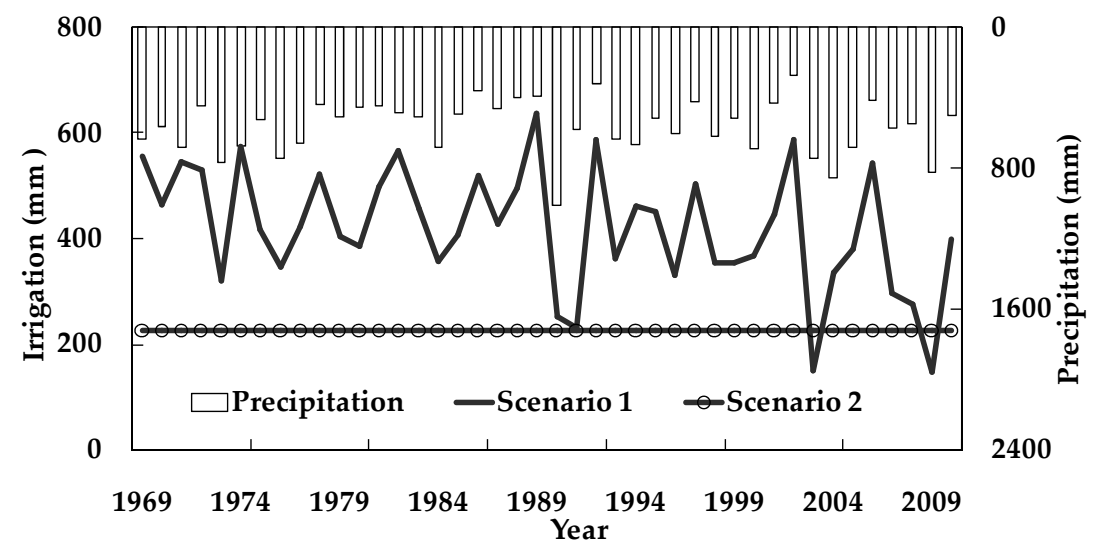

Figure 5. Annual variation in precipitation and total irrigation water under Scenarios 1 and 2 from 1969 to 2010.
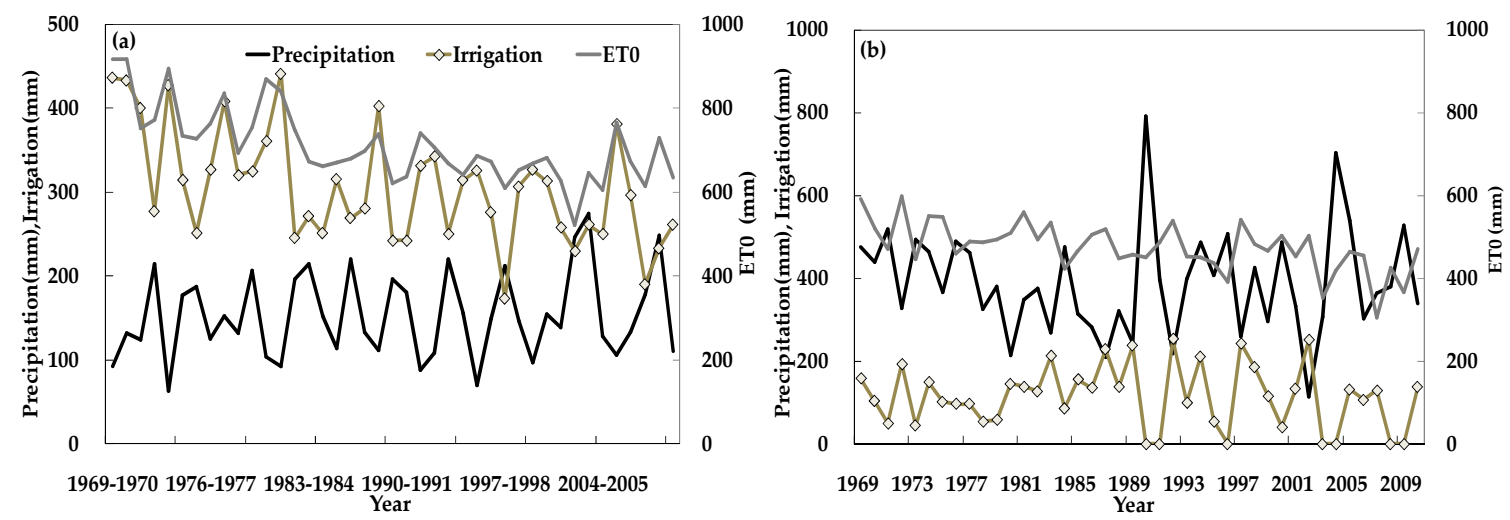

Figure 6. Annual variation in precipitation, irrigation, and reference evapotranspiration during different growing seasons. (a) Winter wheat season; and (b) summer maize season. $\mathrm{ET}_{0}$ is reference evapotranspiration. 
Table 7. Mann-Kendall test and Sen's slope estimator for climate and irrigation variables during the winter wheat and summer maize seasons from 1969 to 2010.

\begin{tabular}{ccccccc}
\hline \multirow{2}{*}{ Variable } & \multicolumn{2}{c}{ Winter Wheat } & \multicolumn{2}{c}{ Summer Maize } & \multicolumn{2}{c}{ Annual } \\
\cline { 2 - 7 } & $\mathbf{Z}$ & $\boldsymbol{\beta}$ & $\mathbf{Z}$ & $\boldsymbol{\beta}$ & $\mathbf{Z}$ & $\boldsymbol{\beta}$ \\
\hline Average & $3.88^{*}$ & 0.04 & $2.10^{* *}$ & 0.02 & - & - \\
temperature & $-3.01^{*}$ & -0.02 & $-1.76^{* *}$ & -0.01 & - & - \\
Wind speed & $2.53^{*}$ & 0.14 & 0.61 & 0.02 & - & - \\
Relative humidity & $-3.80^{*}$ & -0.03 & $-3.79 *$ & -0.04 & - & - \\
Sunshine hours & $-4.71^{*}$ & -4.55 & $-3.60^{*}$ & -2.69 & $-5.58^{*}$ & -3.95 \\
ET $_{0}$ & 0.86 & 0.53 & -0.55 & -0.81 & -0.14 & -0.35 \\
Precipitation & $-3.13^{*}$ & -2.91 & -0.69 & -0.33 & $-2.48^{*}$ & -3.80 \\
Irrigation & &
\end{tabular}

Notes: * Significant at the 0.01 level; ** Significant at the 0.05 level; $\mathrm{ET}_{0}$ : Reference evapotranspiration.

\subsection{Evapotranspiration}

Different irrigation conditions directly affected ET, and there were notable changes among the different scenarios. ET increased with increasing irrigation level, and the simulated average annual ET was 894, 747, and $550 \mathrm{~mm}$ for Scenarios 1, 2, and 3, respectively.

Annual ET rates varied more among scenarios for winter wheat than for summer maize (Figure 7). Compared with the ET of winter wheat and summer maize under Scenario 1, the average ET of winter wheat and summer maize respectively decreased by $20 \%$ and $12 \%$ under Scenario 2 and by $53 \%$ and $24 \%$ under Scenario 3. The relative change in ET during the winter wheat season was higher than that during the summer maize season, which may be attributed to the fact that irrigation had greater influence on winter wheat growth during the summer maize season.
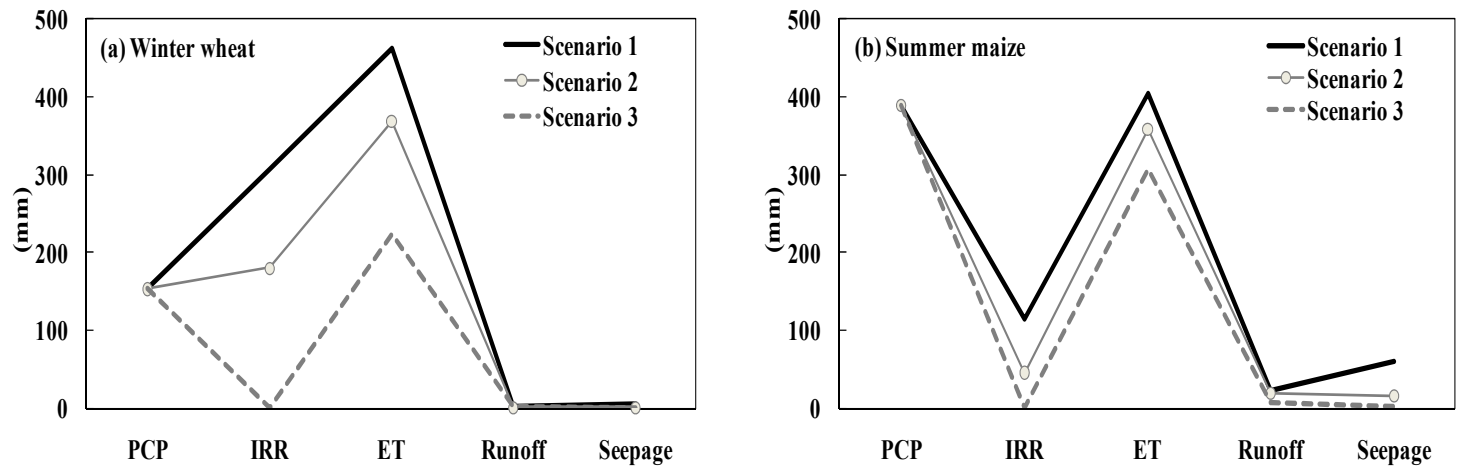

Figure 7. Comparison of precipitation (PCP), irrigation (IRR), ET, runoff, and seepage during winter wheat and summer maize growing seasons under different scenarios. (a) Winter wheat season; and (b) summer maize season.

Annual ET decreased from 1969 to 2010 (Figure 8) with a magnitude of 39, 14, and $7.5 \mathrm{~mm} \cdot$ decade $^{-1}$ under Scenarios 1, 2, and 3, respectively. The trend was significant under Scenario 1 but not under Scenarios 2 and 3. The decrease in $\mathrm{ET}_{0}$ was more pronounced during the winter wheat season compared with the summer maize season (Table 7). Furthermore, the actual ET of winter wheat was larger than that of summer maize. Thus, the annual ET trend was mainly driven by decreased ET during the winter wheat season. 


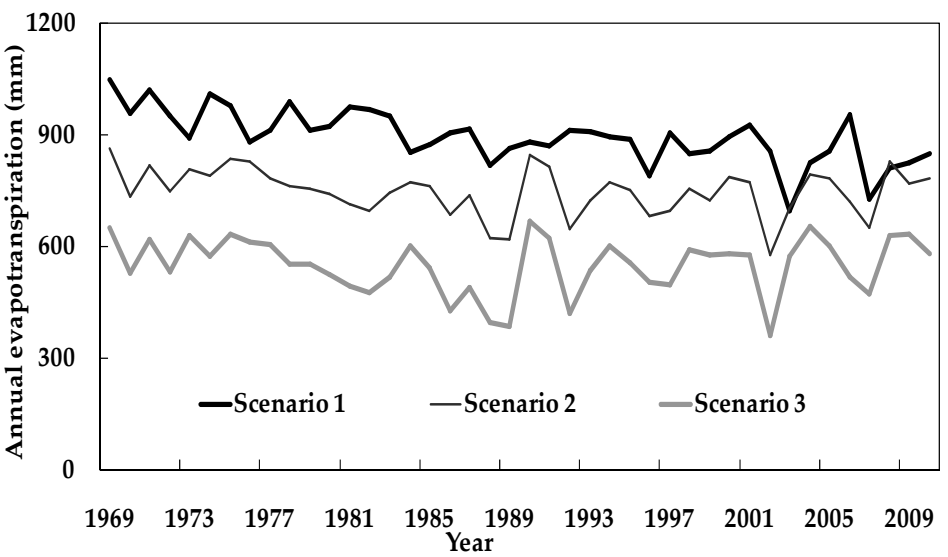

Figure 8. Annual variation in ET under different scenarios from 1969 to 2010.

The difference between crop potential evapotranspiration (PET) and actual ET was used as an index to estimate the water deficit status of crops. Doorenbos and Pruitt [41] defined PET as the amount of water needed to meet water lost through crop ET under non-restricting soil conditions. ET under Scenario 1, which was very close to PET, was used as an approximate value of PET in this study. Thus, larger differences between PET and ET corresponded to more severe crop water deficit. Under the same meteorological conditions, ET increased and water deficit decreased with increasing irrigation level. The annual average difference between PET and ET was $147 \mathrm{~mm}$ for Scenario 2 and $345 \mathrm{~mm}$ for Scenario 3. Water deficit during the winter wheat season was more severe than that during the summer maize season. During the winter wheat season, the annual average water deficit was $97 \mathrm{~mm}$ under Scenario 2 and $239 \mathrm{~mm}$ under Scenario 3; during the summer maize season, the annual average water deficit was $46 \mathrm{~mm}$ under Scenario 2 and $98 \mathrm{~mm}$ under Scenario 3.

\subsection{Seepage and Surface Runoff}

Figures 9 and 10, respectively, show the annual average variation in seepage and surface runoff from 1969 to 2010 under different scenarios. Field seepage and surface runoff are related to the amount, intensity, and duration of precipitation.

Under Scenario 3, the annual average field seepage was less than $2 \mathrm{~mm}$ and seepage only occurred in 2004, 2005, and 2009, though precipitation was higher in other years (e.g., 1973 and 1990). Under Scenario 1, the average field seepage was $65 \mathrm{~mm}$ and the maximum value was $266 \mathrm{~mm}$. Compared with Scenario 3, field seepage occurred more frequently and with a larger magnitude under Scenario 1. Under Scenario 2, field seepage was low except during years with high precipitation. Field seepage under Scenario 2, with an average value of $15 \mathrm{~mm}$ and a maximum of $148 \mathrm{~mm}$, was larger than that under Scenario 3 due to the influence of irrigation.

Annual mean surface runoff was $23 \mathrm{~mm}$ under Scenario 1, $19 \mathrm{~mm}$ under Scenario 2 and $7 \mathrm{~mm}$ under Scenario 3. Differences in annual surface runoff among the scenarios were mainly driven by variation during the summer maize season.

Field seepage and surface runoff were more frequent during the summer maize season (Figure 7) owing to higher precipitation during this time. Field seepage during the summer maize season accounted for over $91 \%$ of annual field seepage under Scenarios 1 and 2, and for $90.7 \%$ under Scenario 3 . Surface runoff during the summer maize season was $21.8 \mathrm{~mm}, 18.1 \mathrm{~mm}$, and $6.1 \mathrm{~mm}$, accounting for $95.8 \%, 93.4 \%$, and $87.5 \%$ of the total annual surface runoff under Scenarios 1, 2, and 3, respectively. Field seepage and surface runoff occurred more frequently under Scenarios 1 and 2 compared with Scenario 3 due to irrigation and subsequently wetter soil under the same precipitation levels. Field seepage and surface runoff did not occur during the winter wheat season, even with irrigation, because precipitation was lower and the soil was often dry. 


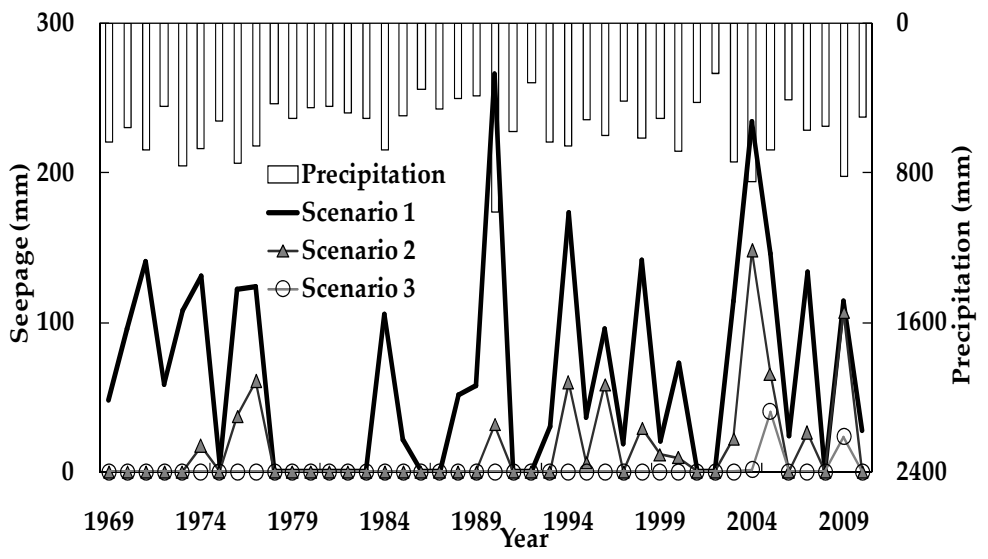

Figure 9. Annual variation in seepage under different scenarios and annual variation in precipitation from 1969 to 2010.

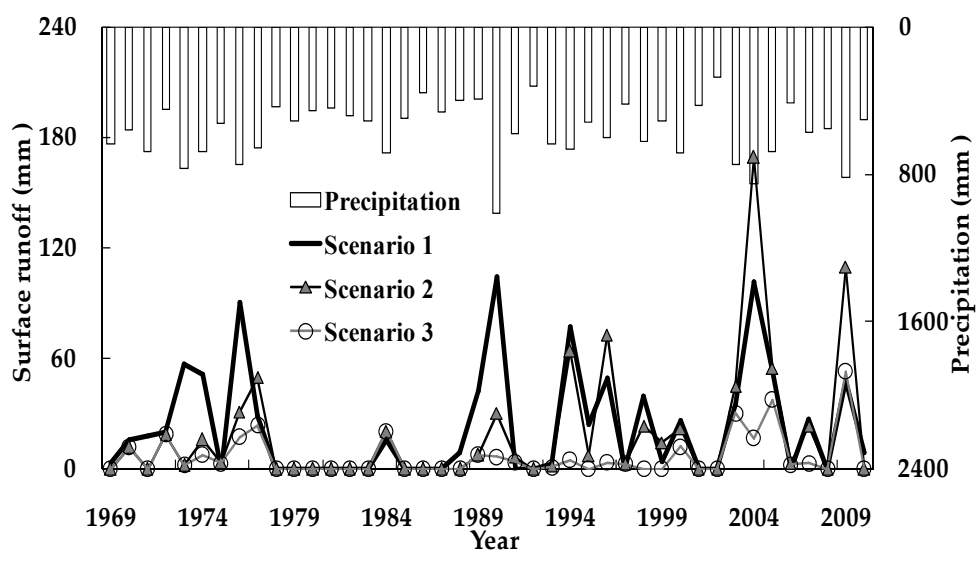

Figure 10. Annual variation in surface runoff under different scenarios and annual variation in precipitation from 1969 to 2010.

\subsection{Grain Yield and Water Use Efficiency}

Winter wheat and summer maize yields were lower for Scenario 3 than for Scenarios 1 and 2 (Table 8). Annual average winter wheat yield for Scenario 3 was only $48 \%$ of that for Scenario 1 and was $54 \%$ of that for Scenario 2 . The different irrigation schemes had less effect on summer maize yield. Annual average summer maize yield for Scenario 3 was $81 \%$ and $94 \%$ of that for Scenarios 1 and 2, respectively. Winter wheat and summer maize yields under Scenario 3 were also unstable compared with those under Scenarios 1 and 2, indicating that timely and proper irrigation is necessary to achieve stable and high crop yield.

Water use efficiency (WUE) in this paper is the same as WPET in the study of Singh et al. [42], which is expressed in terms of crop grain (or seed) yield per unit of ET. The WUE of winter wheat and summer maize is shown in Table 8. Annual average WUE of winter wheat ranged from 0.49 to $2.06 \mathrm{~kg} \cdot \mathrm{m}^{-3}$ and that of summer maize ranged from 1.06 to $2.12 \mathrm{~kg} \cdot \mathrm{m}^{-3}$. High WUE typically did not occur under full irrigation. The highest average WUE for winter wheat was $1.29 \mathrm{~kg} \cdot \mathrm{m}^{-3}$ and occurred under Scenario 2. The highest average WUE for summer maize was $1.61 \mathrm{~kg} \cdot \mathrm{m}^{-3}$ and occurred under Scenario 3, possibly as a result of low ET and yield under this scenario. Furthermore, annual variation in WUE of both winter wheat and summer maize was most obvious when no irrigation was used. Therefore, irrigation is an important practice for stable WUE. 
Table 8. Grain yield and WUE of winter wheat and summer maize from 1969 to 2010 under different scenarios.

\begin{tabular}{|c|c|c|c|c|c|c|c|}
\hline \multirow{3}{*}{ Crop } & \multirow{3}{*}{ Statistic } & \multicolumn{2}{|c|}{ Scenario 1} & \multicolumn{2}{|c|}{ Scenario 2} & \multicolumn{2}{|c|}{ Scenario 3} \\
\hline & & Yield & WUE $^{a}$ & Yield & WUE & Yield & WUE \\
\hline & & $\left(\mathrm{kg} \cdot \mathrm{ha}^{-1}\right)$ & $\left(\mathrm{kg} \cdot \mathrm{m}^{-3}\right)$ & $\left(\mathrm{kg} \cdot \mathrm{ha}^{-1}\right)$ & $\left(\mathrm{kg} \cdot \mathrm{m}^{-3}\right)$ & $\left(\mathrm{kg} \cdot \mathrm{ha}^{-1}\right)$ & $\left(\mathrm{kg} \cdot \mathrm{m}^{-3}\right)$ \\
\hline \multirow{5}{*}{$\begin{array}{l}\text { Winter } \\
\text { wheat }\end{array}$} & Max & 6272 & 1.46 & 5697 & 1.81 & 4460 & 2.06 \\
\hline & Min & 3903 & 0.86 & 3142 & 0.79 & 1007 & 0.49 \\
\hline & Mean & 5284 & 1.15 & 4709 & 1.29 & 2548 & 1.15 \\
\hline & Stdev & 575 & 0.14 & 598 & 0.21 & 895 & 0.36 \\
\hline & $\mathrm{CV}$ & 0.11 & 0.12 & 0.13 & 0.17 & 0.35 & 0.31 \\
\hline \multirow{5}{*}{$\begin{array}{l}\text { Summer } \\
\text { maize }\end{array}$} & Max & 7955 & 1.87 & 7522 & 1.88 & 7417 & 2.12 \\
\hline & Min & 3204 & 1.06 & 3206 & 1.06 & 2508 & 1.13 \\
\hline & Mean & 6146 & 1.51 & 5265 & 1.46 & 4963 & 1.61 \\
\hline & Stdev & 1046 & 0.17 & 1029 & 0.18 & 1143 & 0.23 \\
\hline & $\mathrm{CV}$ & 0.17 & 0.11 & 0.20 & 0.13 & 0.23 & 0.15 \\
\hline
\end{tabular}

Notes: ${ }^{a}$ Water use efficiency is expressed in terms of crop grain (or seed) yield per unit ET.

\subsection{Effects of Meteorological Variables on Irrigation}

Atmospheric evaporative demand, which is affected by several meteorological variables, had a large influence on annual variation in irrigation level [5]. The different meteorological variables investigated in this study are shown in Figure 11. Average annual temperature during the winter wheat and summer maize season was $8.2^{\circ} \mathrm{C} \pm 0.70{ }^{\circ} \mathrm{C}$ and $25.2^{\circ} \mathrm{C} \pm 0.69^{\circ} \mathrm{C}$, respectively. Average annual wind speed was $2.0 \pm 0.43 \mathrm{~m} \cdot \mathrm{s}^{-1}$ during the winter wheat season and $1.7 \pm 0.44 \mathrm{~m} \cdot \mathrm{s}^{-1}$ during the summer maize season. Average annual relative humidity was $61.5 \% \pm 3.92 \%$ during the winter wheat season and $75.5 \% \pm 3.31 \%$ during the summer maize season. Average annual sunshine hours was $6.7 \pm 0.6 \mathrm{~h}$ during winter wheat season and $7.3 \pm 0.88 \mathrm{~h}$ during the summer maize season. Table 7 shows the results of Mann-Kendall tests and Sen's slope estimators for different meteorological variables from 1969 to 2010. Relative humidity increased from 1969 to 2010 for both seasons; the trend was significant for the winter wheat season but not for the summer maize season. The average temperature during both seasons significantly increased over the study period. As for the wind speed and sunshine hours there was a significantly decreasing trend. Under the influences of these meteorological variables, $\mathrm{ET}_{0}$, calculated with the Penman-Montieth equation embedded in SWAT, significantly decreased over the study period.

The Pearson correlation coefficient $r$ was used to evaluate correlations between meteorological variables and $\mathrm{ET}_{0}$, and the correlations varied between seasons (Table 9). For the winter wheat season, $\mathrm{ET}_{0}$ was most strongly correlated with wind speed $(\mathrm{r}=0.696, p<0.01)$, followed by relative humidity $(\mathrm{r}=-0.585, p<0.01)$ and sunshine hours $(\mathrm{r}=0.553, p<0.01)$. The correlation coefficient between $\mathrm{ET}_{0}$ and average temperature was $-0.261(p>0.05)$, indicating that temperature did not strongly influence $\mathrm{ET}_{0}$. This result reflects the 'Evaporation paradox' phenomenon, which was also reported by Zhang et al. [43] and Ma et al. [44]. In general, increasing average temperature and decreasing wind speed and sunshine hours caused $\mathrm{ET}_{0}$ to decrease at a rate of $45.5 \mathrm{~mm} \cdot \mathrm{decade}^{-1}$ (Table 7). For the summer maize season, $\mathrm{ET}_{0}$ was most strongly correlated with sunshine hours $(\mathrm{r}=0.813, p<0.01)$, followed by relative humidity $(\mathrm{r}=-0.738, p<0.01)$ and wind speed $(\mathrm{r}=0.409, p<0.01)$. Average temperature was positively correlated with $\mathrm{ET}_{0}$, but the correlation was not significant $(\mathrm{r}=0.272$, $p>0.05)$, which showed $\mathrm{ET}_{0}$ increasing with the average temperature increasing but the influence of average temperature on $\mathrm{ET}_{0}$ was not obvious. $\mathrm{ET}_{0}$ decreased during the summer maize season at a rate of $26.9 \mathrm{~mm} \mathrm{decade}^{-1}$ (Table 7), which was less than that during winter wheat season for the decrease of $\mathrm{ET}_{0}$ was mainly influenced by the decrease of wind speed and sunshine hours. 

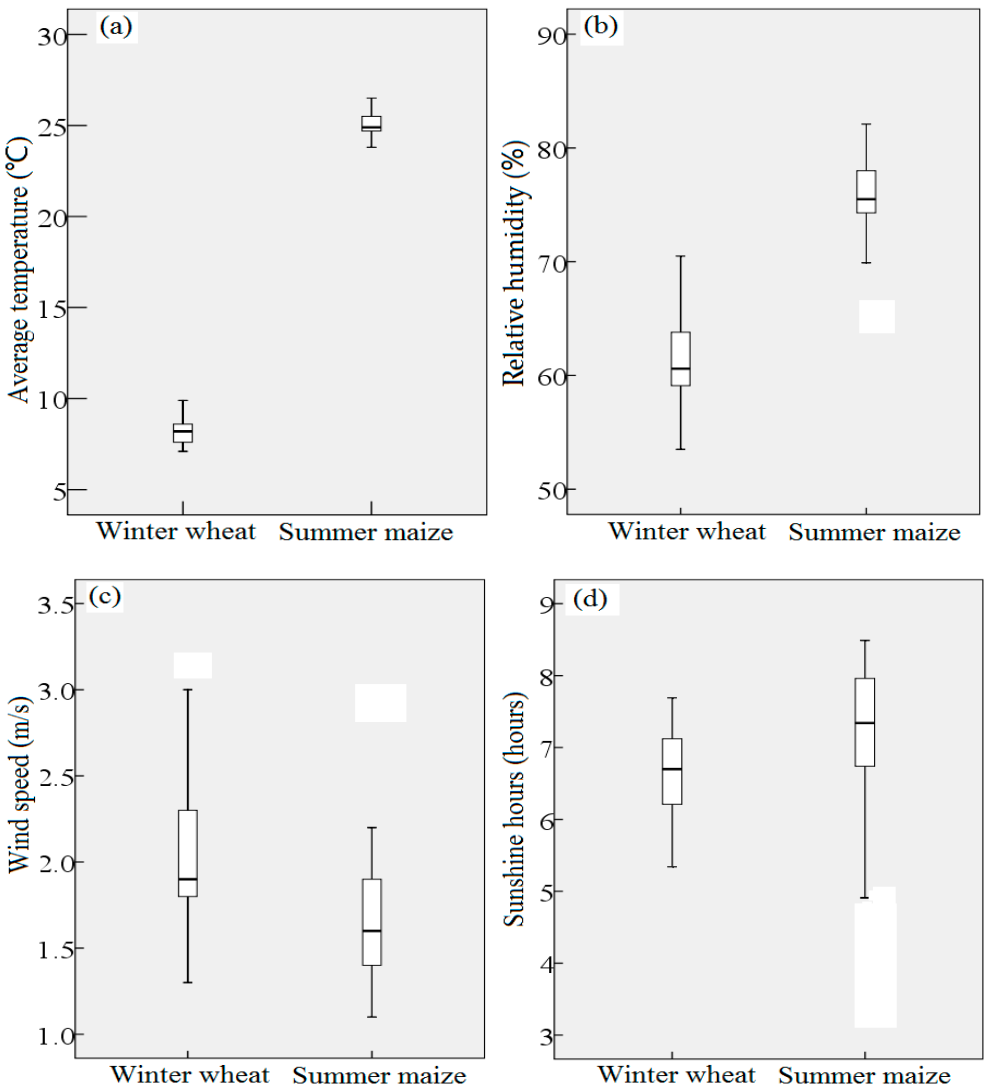

Figure 11. Variation in meteorological variables over the study period. (a) Average temperature; (b) relative humidity; (c) wind speed; and (d) sunshine hours.

Table 9. Coefficients of correlations between $\mathrm{ET}_{0}$ and meteorological variables during different seasons from 1969 to 2010.

\begin{tabular}{ccccc}
\hline \multirow{2}{*}{ Variable } & \multicolumn{2}{c}{ Winter Wheat } & \multicolumn{2}{c}{ Summer Maize } \\
\cline { 2 - 5 } & Correlation Coefficient & $p$ Values & Correlation Coefficient & $p$ Values \\
\hline Average temperature & -0.261 & 0.103 & 0.272 & 0.081 \\
Wind speed & 0.696 & $0.000^{*}$ & 0.409 & $0.009^{*}$ \\
Relative humidity & -0.585 & $0.000^{*}$ & -0.738 & $0.000^{*}$ \\
Sunshine hours & 0.553 & $0.000^{*}$ & 0.813 & $0.000^{*}$ \\
\hline
\end{tabular}

Notes: $p$ values indicate the significance level of the correlation coefficients. ${ }^{*}$ Significant correlation at the 0.01 level.

In general, a decrease in $\mathrm{ET}_{0}$ reduces crop water demand, whereas decreased precipitation increases the required irrigation level. Irrigation level was positively correlated with $\mathrm{ET}_{0}$ and negatively correlated with precipitation during both growing seasons. The correlation between irrigation and $\mathrm{ET}_{0}$ was significant during different growth seasons, whereas the correlation between irrigation and precipitation was significant during the winter wheat season only (Table 10). The decreasing trend of $\mathrm{ET}_{0}$ was significant at the 0.01 level while that of precipitation was not significant (Table 7), which finally resulted in the decreasing irrigation in the study area. 
Table 10. Coefficients of correlation between irrigation and $\mathrm{ET}_{0}$, precipitation during different seasons.

\begin{tabular}{ccccc}
\hline \multirow{2}{*}{ Variable } & \multicolumn{2}{c}{ Winter Wheat } & \multicolumn{2}{c}{ Summer Maize } \\
\cline { 2 - 5 } & Correlation Coefficient & $p$ Values & Correlation Coefficient & $p$ Values \\
\hline $\mathrm{ET}_{0}$ & 0.806 & $0.000^{*}$ & 0.515 & $0.000^{*}$ \\
Precipitation & -0.430 & $0.005^{*}$ & -0.276 & 0.077 \\
\hline
\end{tabular}

Notes: $p$ values indicate the significant level of the correlation coefficients. ${ }^{*}$ Significant correlation at the 0.01 level. $\mathrm{ET}_{0}$ : reference evapotranspiration.

\section{Discussion}

\subsection{Validation and Uncertainty Analysis}

Accurate simulation of crop PET and irrigation water requirement (IWR) is important for rational use of water resources in agricultural watersheds. Crop and soil parameters in the SWAT model may greatly influence simulated PET and IWR. Thus, sensitivity analyses were conducted for these parameters using the LH-OAT method to evaluate their influences on simulated PET and IWR (Table 11).

Soil moisture can have a large impact on crop PET and IWR, but compared with crop parameters, the influence of soil parameters on crop PET and IWR was small. Among the tested soil parameters, only bulk density and soil AWC were influential. Changes in clay, silt, and sand contents had almost no impact on crop PET or IWR, possibly because there was no water stress.

Crop PET and IWR were greatly affected by crop growth status (reflected by LAI). The LAI curve included six parameters with varying influences on PET and IWR.

Table 11. Rank of parameter sensitivity for annual crop PET and IWR.

\begin{tabular}{cccl}
\hline Parameters & PET & IWR & \\
\hline FRGRW1 & 1 & 1 & Fraction of PHU at point 1 on the optimal leaf area development curve \\
BLAI & 2 & 4 & Maximum potential leaf area index \\
DLAI & 3 & 2 & Fraction of growing season when leaf area declines \\
FRGRW2 & 4 & 7 & Fraction of PHU at point 2 on the optimal leaf area development curve \\
LAIMX2 & 5 & 5 & Fraction of the maximum LAI at point 2 on the optimal leaf area development curve \\
LAIMX1 & 6 & 6 & Fraction of the maximum LAI at point 1 on the optimal leaf area development curve \\
Soil AWC & 7 & 3 & Soil available water content \\
Bulk density & 8 & 8 & Soil bulk density \\
\hline
\end{tabular}

FRGRW1 had the largest influence on simulated PET, followed by BLAI; and IWR was most strongly affected by FRGRW1, followed by DLAI. Based on these results, crop and soil parameters, particularly FRGRW1, BLAI, and DLAI, should be carefully calibrated and validated based on field data for accurate PET and IWR simulations.

Uncertainty of these parameters will lead to uncertainty of estimated PET and IWR. The model was run over 300 times while changing the values of crop and soil parameters within realistic ranges. The $95 \%$ confidence interval (CI) for simulated PET and IWR of winter wheat was $(379,557)$ and $(165$, $432)$, and that for summer maize was $(321,497)$ and $(0,255)$. For winter wheat, simulated PET ranged between 374 and $555 \mathrm{~mm}$ and simulated IWR ranged between 174 and $442 \mathrm{~mm}$ from 1969 to 2010 . For summer maize, simulated PET ranged between 271 and $467 \mathrm{~mm}$ and IWR ranged between 0 and $253 \mathrm{~mm}$. Almost all of the estimated results given in Section 3 were within these 95\% CIs (Table 12), which represent all possible results given the uncertainty of crop and soil parameters. These results provide comprehensive information for the sustainable use of water resources. 
Table 12. Percent of simulated PET and IWR within the $95 \%$ CI for winter wheat and summer maize.

\begin{tabular}{ccccc}
\hline & $\begin{array}{c}\text { Simulated PET of } \\
\text { Winter Wheat }\end{array}$ & $\begin{array}{c}\text { Simulated IWR of } \\
\text { Winter Wheat }\end{array}$ & $\begin{array}{c}\text { Simulated PET of } \\
\text { Summer Maize }\end{array}$ & $\begin{array}{c}\text { Simulated IWR of } \\
\text { Summer Maize }\end{array}$ \\
\hline $\begin{array}{c}\text { Percent within the } \\
95 \% \text { CI }\end{array}$ & $98 \%$ & $93 \%$ & $93 \%$ & $100 \%$ \\
\hline
\end{tabular}

\subsection{Uncertainty of the Results}

According to simulated hydrologic variables and water demand of cropping systems at the field scale, appropriate irrigation schedules should be developed for rational use of water resources in arid areas. However, there are some limitations for the establishment of water-saving irrigation schedules.

Simulated crop growth was overestimated during the senescence stage, which influenced simulated ET. For example, the average simulated PET for winter wheat from 1992 to 2009 in this study was $442 \mathrm{~mm}$; based on observational data in YCES, Chen et al. [45] reported an average PET of about $457 \mathrm{~mm}$ during the same period. For summer maize, average simulated PET was $405 \mathrm{~mm}$ in our study and $300-400 \mathrm{~mm}$ in Chen et al. [45]. As crop PET is the main basis for irrigation schedules, this overestimation will result in some inaccuracies in the development of water-saving irrigation schemes, especially in areas with water shortages. Though crop growth estimations have been improved in new versions of SWAT [46], model parameters should be carefully calibrated and validated based on field data to effectively guide irrigation management.

Irrigation is essential to crop growth in arid regions, and effective irrigation management is critical for sustainable and effective water use. Irrigation impacts hydrologic balance, and the SWAT model can simulate hydrologic processes resulting from different irrigation schedules specified by users. However, SWAT models irrigation strategies without considering future meteorological conditions, which may result in high irrigation during years with abundant precipitation. For example, average precipitation was $675 \mathrm{~mm}$ in 1974 and the simulated irrigation level under full irrigation was $576 \mathrm{~mm}$ because irrigation sometimes occurred before rain events (Figure 12). In practice, farmers set irrigation schedules according to meteorological forecasts before crops are irrigated.

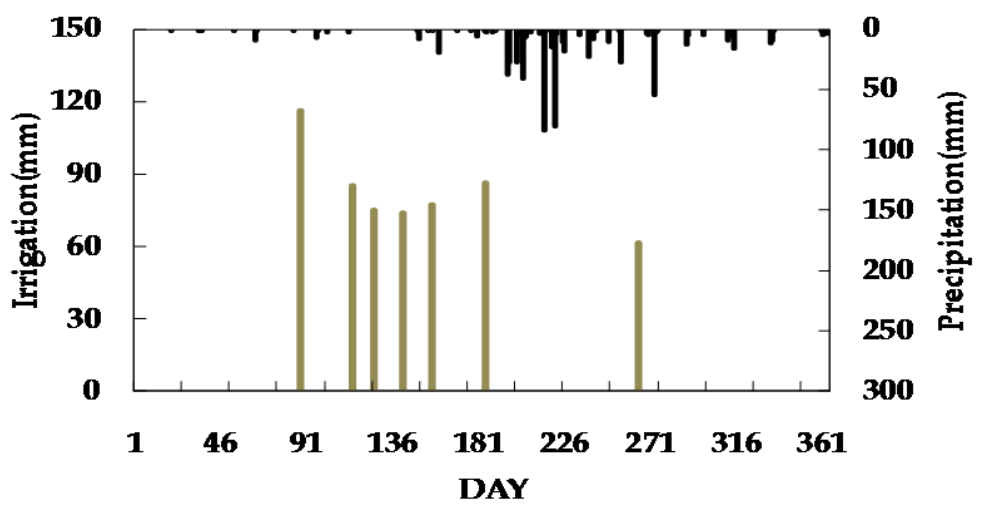

Figure 12. Precipitation and simulated irrigation under Scenario 1 in 1974.

For scheduled irrigation scenarios, users should predefine irrigation level and time. In reality, irrigation levels should be the same each year. However, simulated irrigation level varied somewhat among years because the simulated 'actual' irrigation level was sometimes lower than the predefined level. In the SWAT model, the fraction of water that goes to 'soil water storage' is defined as the 'actual' irrigation amount. For example, in 1993 and 1998, soil was saturated before all predefined irrigation events were executed, leading variation of the 'actual' irrigation level from the predefined level. Crop WUE will be calculated according to the 'actual' irrigation level but, in practice, it should be calculated based on the predefined level. Furthermore, though irrigation level and time are predefined, farmers 
should also adjust these settings according to future meteorological conditions, which are not currently incorporated in the SWAT model.

\subsection{Credibility of Results}

Our results indicate that the annual irrigation requirements of the winter wheat-summer maize system under Scenario 1 decreased from 1969 to 2010, which is consistent with the study of Liu et al. [6]. Similar results have also been found in regions near our study area. Hu et al. [47] reported a decrease in IWR for winter wheat in the northern part of the North China Plain (NCP) from 1981 to 2010, and Huan et al. [48] reported a decrease in irrigation requirements for summer maize from 1980 to 2014 in the middle of Shandong Province.

This study showed that the decreasing of wind speed and sunshine hours and the increasing of average temperature and relative humidity resulted in the decreasing trend of $\mathrm{ET}_{0}$, and thereby winter wheat and summer maize irrigation requirements decreased. Wind speed had the strongest correlation with winter wheat $\mathrm{ET}_{0}$. Similarly, Zhang et al. [39] reported a strong correlation between wind speed and $\mathrm{ET}_{0}$ in the Yellow River Basin, with correlation coefficients ranging from 0.66 to 0.99. During the summer maize season, $\mathrm{ET}_{0}$ was most strongly correlated with sunshine hours in this study. Likewise, Song et al. [49] reported that net radiation was the most important factor influencing $\mathrm{ET}_{0}$ in the NCP. Temperature was not a dominant factor in either season, which could be similarly found in the study of Zhang et al. [39].

Annual irrigation requirement exhibited large annual variation, mainly due to corresponding variations in precipitation and $\mathrm{ET}_{0}$. The $\mathrm{CV}$ values for $\mathrm{ET}_{0}$ and precipitation were 0.12 and 0.33 , respectively. Irrigation was mainly necessary during the winter wheat season, which influenced the amount of and variation in annual irrigation requirements for the winter wheat-summer maize cropping system.

Annual variation in crop PET has been discussed in many studies, but few have focused on crop water consumption under deficit or no irrigation. In this paper, the decrease in ET under Scenario 1 was similar to results reported by other researchers. However, some studies have reported different rates and/or direction of the ET trend, and these differences may be due to the estimation method and scale. For example, based on observational data in YCES, Chen et al. [45] reported that ET decreased from 1992 to 2009, with rates of 20.8 and $20.2 \mathrm{~mm} \cdot$ decade $^{-1}$ for winter wheat and summer maize, respectively. Liu et al. [50] estimated ET for winter wheat and summer maize in North China from 1950 to 2000 as the product of the crop coefficient and $\mathrm{ET}_{0}$; their results suggested that, in most locations, ET for winter wheat and summer maize significantly decreased over the past 50 years, with rates of $0.9-19.2 \mathrm{~mm}$ and $8.3-24.3 \mathrm{~mm}$ per decade, respectively. Yang et al. [51,52] reported that ET for winter wheat and summer maize in the Huang-Huai-Hai Plain calculated by SIMETAW (Simulation Evapotranspiration of Applied Water) significantly decreased from 1960 to 2009. Winter wheat and summer maize ET also decreased under Scenarios 2 and 3 in this study, though the trends were not significant. Under Scenario 1, crops grew under optimal condition and the decreasing trend in ET was similar to that of $\mathrm{ET}_{0}$. Lower irrigation levels result in more severe water stress and more obvious differences between crop $\mathrm{ET}$ and $\mathrm{ET}_{0}$.

Seepage and surface runoff mainly occurred during the summer maize season, and runoff during July and August accounted for $70 \%$ of the annual total [6]. Increased irrigation levels generate more seepage, wetter soil, and more surface runoff. Surface runoff during the summer maize season should be fully utilized to compensate for water deficits, which mainly occurred during the winter wheat season in our study area.

\section{Conclusions}

We used the SWAT2000 parameterized by Liu et al. [6] to simulate the water balance and water demand of a winter wheat-summer maize agro-ecosystem under different irrigation scenarios in an irrigation district of the Lower Yellow River Basin, a primary grain production region of China. 
From 1969 to 2010, the average annual irrigation level under Scenario 1 (full irrigation) was the highest among the three irrigation scenarios. Average annual ET, field seepage, and surface runoff decreased with reduced irrigation level.

Under the effects of various meteorological variables, average annual irrigation and crop ET under Scenario 1 significantly decreased over the study period. The intensity and duration of precipitation, as well as soil characteristics, influenced field seepage and surface runoff. Field seepage and surface runoff occurred more frequently in years with high precipitation and during the summer maize season.

The main factors causing annual variation in hydrological processes during different crop growing seasons were characterized. Irrigation and ET were dominant factors during the winter wheat season, whereas field seepage and surface runoff had the strongest influence during the summer maize season.

According to the above results, agricultural water cycles can be regulated to achieve sustainable and efficient water use in water-shortage areas. For example, if all winter wheat-summer maize planting systems in irrigation districts along the Lower Yellow River Basin are irrigated under full levels, $64.8 \times 10^{8} \mathrm{~m}^{3}$ of water will be required. This amount is equal to about $16 \%$ of the annual runoff volume at the Huayuankou Hydrological Station, which is located at the uppermost part of the Yellow River in the study area. It is impossible to irrigate all crops under full irrigation due to serious shortages in water availability from the Yellow River. Furthermore, full irrigation is not always necessary, as frequent and heavy irrigation does not always lead to high WUE. As winter wheat-summer maize is the main cropping pattern in the study area and water deficit mainly occurs during the winter wheat season, it is necessary to properly irrigate winter wheat based on soil water content and make full use of precipitation and surface runoff during the summer maize season. This strategy will help to cope with the limited water resources of the irrigation districts along the lower reaches of the Yellow River.

Acknowledgments: This study was supported by the National Natural Science Foundation of China (No. 41601019), the Program for Science \& Technology Innovation Talents in Universities of Henan Province (15HASTIT046), the Science and Technology Project of Henan Province (152102110095), the Key Scientific Research Project of Henan Province Universities (15A570008), and the North China University of Water Resources and Electric Power high-level personnel starting project (No. 201214). The authors are grateful to the anonymous reviewers for their valuable comments and suggestions.

Author Contributions: This paper was designed by Yi Luo and Lei Liu. Lei Liu performed the data analysis and wrote the paper. Yi Luo and Chansheng He help with revising the paper. Jianqin Ma and Tiegang Liu conceived the main ideas of the paper and helped with data analysis and writing the paper.

Conflicts of Interest: The authors declare no conflict of interest.

\section{References}

1. Young, R.A.; Onstad, C.A.; Borsch, D.D.; Anderson, W.P. AGNPS: A Nonpoint-Source Pollution model for evaluating agricultural watersheds. J. Soil Water Conserv. 1989, 44, 168-173.

2. Williams, J.R.; Jones, C.A.; Kiniry, J.R.; Spanel, D.A. The EPIC crop growth model. Trans. ASAE 1989, 32, 497-511. [CrossRef]

3. Arnold, J.G.; Allen, P.M.; Bernhardt, G. A comprehensive surface-ground water flow model. J. Hydrol. 1993, 142, 47-69. [CrossRef]

4. $\quad$ Neitsch, S.L.; Arnold, J.G.; Kiniry, J.R.; Williams, J.R.; King, K.W. Soil and Water Assessment Tool Theoretical Documentation, Version 2000; Grassland, Soil and Water Research Laboratory, Agricultural Research Service: Temple, TX, USA, 2002.

5. Luo, Y.; He, C.; Sophocleous, M.; Yin, Z. Assessment of crop growth and soil water modules in SWAT2000 using extensive field experiment data in an irrigation district of the Yellow River Basin. J. Hydrol. 2008, 352, 139-156. [CrossRef]

6. Liu, L.; Luo, Y.; He, C.; Lai, J.B.; Li, X.B. Roles of the Combined Irrigation, Drainage, and Storage of the Canal Network in Improving Water Reuse in the Irrigation Districts along the Lower Yellow River, China. J. Hydrol. 2010, 391, 157-174. [CrossRef] 
7. Arnold, J.G.; Allen, P.M. Estimating hydrologic budgets for three Illinois watershed. J. Hydrol. 1996, 176, 57-77. [CrossRef]

8. Rosenthal, W.D.; Hoffman, D.W. Hydrologic modeling/GIS as an aid in locating monitoring sites. Trans. ASAE 1999, 42, 1591-1598. [CrossRef]

9. Spruill, C.A.; Workman, S.R.; Taraba, J.L. Simulation of daily and monthly stream discharge from small watersheds using the SWAT model. Trans. ASAE 2000, 43, 1431-1439. [CrossRef]

10. Chu, T.W.; Shirmohammadi, A.; Montas, H.; Sadeghi, A. Evaluation of the SWAT model's sediment and nutrient components in the piedomont physiographic region of maryland. Trans. ASAE 2004, 47, 1523-1538. [CrossRef]

11. Gosain, A.K.; Rao, S.; Srinivasan, R.; Reddy, N.G. Return-flow Assessment for Irrigation Command in the Palleru River Basin using SWAT Model. Hydrol. Process. 2005, 19, 673-682. [CrossRef]

12. Zhang, A.; Zhang, C.; Fu, G.; Wang, B.; Bao, Z.; Zheng, H. Assessments of impacts of climate change and human activities on runoff with SWAT for the Huifa river basin, northeast China. Water Resour. Manag. 2012, 26, 2199-2217. [CrossRef]

13. Benaman, J.; Shoemaker, C.; Haith, D. Calibration and validation of soil and water assessment tool on an agricultural watershed in upstate New York. J. Hydrol. Eng. 2005, 10, 363-374. [CrossRef]

14. Bouraoui, F.; Benabdallah, S.; Jrad, A.; Bidoglio, G. Application of the SWAT model on the Medjerda river basin (Tunisia). Phys. Chem. Earth 2005, 30, 497-507. [CrossRef]

15. Mishra, A.; Kar, S. Modeling hydrologic processes and NPS pollution in a small watershed in subhumid subtropics using SWAT. J. Hydrol. Eng. 2012, 17, 445-454. [CrossRef]

16. Bhumika, U.; Madan, K.J.; Arbind, K.V. Assessing climate change impact on water balance components of a river basin using SWAT model. Water Resour. Manag. 2015, 29, 4767-4785.

17. Van Griensven, A.; Bauwens, W. Application and evaluation of ESWAT on the Dender Basin and the Wister Lake Basin. Hydrol. Process. 2005, 19, 827-838. [CrossRef]

18. Eckhardt, K.; Arnold, J.G. Automatic calibration of a distributed catchment model. J. Hydrol. 2001, 251, 103-109. [CrossRef]

19. Ray, S.S.; Dadhwal, V.K. Estimation of crop evapotranspiration of irrigation command area using remote sensing and GIS. Agric. Water Manag. 2001, 49, 239-249. [CrossRef]

20. Launay, M.; Guerif, M. Assimilating remote sensing data into a crop model to improve predictive performance for spatial applications. Agri. Ecosyst. Environ. 2005, 111, 321-339. [CrossRef]

21. Groeneveld, D.P.; Baugh, W.M.; Sanderson, J.S.; Cooper, D.J. Annual groundwater evapotranspiration mapped from single satellite scenes. J. Hydrol. 2007, 344, 146-156. [CrossRef]

22. Santhi, C.; Muttiah, R.S.; Arnold, J.G.; Srinivasan, R. A gis-based regional planning tool for irrigation demand assessment and saving using SWAT. Trans. ASAE 2005, 48, 137-147. [CrossRef]

23. Cabelguenne, M.; Debaeke, P. Experimental determination and modelling of the soil water extraction capacities of crops of maize, sunflower, soya bean, sorghum and wheat. Plant Soil 1998, 202, 175-192. [CrossRef]

24. Borrás, L.; Maddonni, G.A.; Otegui, M.E. Leaf senescence in maize hybrids: Plant population, row spacing and kernel set effects. Field Crops Res. 2003, 82, 13-26. [CrossRef]

25. Leeper, R.A.; Runge, E.C.A.; Walker, W.M. Effect of plant-available stored soil moisture on corn yields: I. Constant climatic conditions. Agron. J. 1974, 66, 723-727. [CrossRef]

26. Calviño, P.A.; Andrage, F.H.; Sadras, V.O. Maize yield as affected by water availability, soil depth, and crop management. Agron. J. 2003, 95, 275-281. [CrossRef]

27. Sárvári, M. Impact of nutrient supply, sowing time and plant density on maize yields. Acta Agron. Hung. 2005, 53, 59-70. [CrossRef]

28. Cross, H.Z.; Zuber, M.S. Prediction of flowering dates in maize based on different methods of estimating thermal units. Agron. J. 1972, 64, 351-355. [CrossRef]

29. Shaykewich, C.F. An appraisal of cereal crop phenology modeling. Can. J. Plant Sci. 1995, 75, 329-341. [CrossRef]

30. Yan, W.; Hunt, L.A. An Equation for modelling the temperature response of plants using only the cardinal temperatures. Ann. Bot. 1999, 84, 607-614. [CrossRef]

31. Lin, Q.; Shi, Y.; Wei, D.B. Relations between soil water and yield formation and determination of Water-saving irrigation scheme in Winter Wheat. Acta Agric. Boreali-Sin. 1998, 13, 1-4. (In Chinese) 
32. Zhu, Z.X.; Zhang, J.C. Crop Water Stress and Drought; Henan Science and Technology Press: Zhengzhou, China, 1991.

33. Zhang, Y.Q.; Mao, X.S.; Sun, H.Y.; Li, W.J.; Yu, H.N. Effects of drought stress on chlorophyll fluorescence of winter wheat. Chin. J. Eco-Agric. 2002, 10, 13-15.

34. Zhang, S.; Zhou, X.; Mu, Z.; Shan, L.; Liu, X. Effects of different irrigation patterns on root growth and water use efficiency of maize. Trans. Chin. Soc. Agric. Eng. 2009, 25, 1-6.

35. Li, J.M.; Inanaga, S.; Li, Z.; Eneji, A.E. Optimizing irrigation scheduling for winter wheat in the North China Plain. Agric. Water Manag. 2005, 76, 8-23. [CrossRef]

36. Liu, Y.; Cai, J.B.; Cai, L.G.; Pereira, L.S. Analysis of irrigation scheduling and water balance for an irrigation district at lower reaches of the Yellow River. J. Hydraul. Eng. 2005, 36, 701-708. (In Chinese)

37. Fang, Q.; Ma, L.; Yu, Q.; Ahuja, L.R.; Malone, R.W.; Hoogenboom, G. Irrigation strategies to improve the water use efficiency of wheat-maize double cropping systems in North China Plain. Agric. Water Manag. 2010, 97, 1165-1174. [CrossRef]

38. Wu, K. Water regime change characteristics and sustainable development of irrigation areas diverted water from Lower Reach of the Huanghe River. J. Irrig. Drain. 2003, 22, 45-47, 66. (In Chinese)

39. Mann, H.B. Non-parametric tests against trend. Econometrica 1945, 13, 245-259. [CrossRef]

40. Kendall, M.G. Rank Correlation Methods; Charles Griffin: London, UK, 1975.

41. Sen, P.K. Estimates of the regression coefficient based on Kendall's tau. J. Am. Stat. Assoc. 1968, 63, 1379-1389. [CrossRef]

42. Singh, R.; Van Dam, J.C.; Feddes, R.A. Water productivity analysis of irrigated crops in Sirsa district, India. Agric. Water Manag. 2006, 82, 253-278. [CrossRef]

43. Zhang, Q.; Xu, C.Y.; Chen, X.H. Reference evapotranspiration changes in China: Natural processes or human influences? Theor. Appl. Climatol. 2011, 103, 479-488. [CrossRef]

44. Ma, X.N.; Zhang, M.; Li, Y.; Wang, S.; Ma, Q.; Liu, W. Decreasing potential evapotranspiration in the Huanghe watershed in climate warming during 1960-2010. J. Geogr. Sci. 2012, 22, 977-988. [CrossRef]

45. Chen, B.; Ouyang, Z.; Cheng, W.X.; Liu, L.P. Water consumption for winter wheat and summer maize in the North China Plain in Recent 50 Years. J. Nat. Resour. 2012, 27, 1186-1199. (In Chinese)

46. Neitsch, S.L.; Arnold, J.G.; Kiniry, J.R.; Williams, J.R. Soil and Water Assessment Tool Theoretical Documentation, Version 2009; Grassland, Soil and Water Research Laboratory, Agricultural Research Service: Temple, TX, USA, 2011.

47. Hu, W.; Yan, C.R.; Li, Y.C.; Liu, Q. Impacts of climate change on winter wheat growing period and irrigation water requirements in the north china plain. Acta Ecol. Sin. 2014, 34, 2367-2377. (In Chinese) [CrossRef]

48. Huan, H.J.; Yang, Z.Q.; Liu, Y.; Xia, F.H.; Yang, K. Temporal and spatial variation of water deficit and irrigation requirement for corn in the middle of Shandong province in China. Jiangsu Agric. Sci. 2016, 44, 342-347. (In Chinese)

49. Song, Z.W.; Zhang, H.L.; Snyder, R.L.; Anderson, F.E.; Chen, F. Distribution and trends in reference evapotranspiration in the North China Plain. J. Irrig. Drain. Eng. 2010, 136, 240-247. [CrossRef]

50. Liu, X.Y.; Li, Y.Z.; Hao, W.P. Trend and causes of water requirement of main crops in North China in recent 50 years. Trans. CSAE 2005, 21, 155-159. (In Chinese)

51. Yang, X.L.; Song, Z.W.; Wang, H.; Shi, Q.H.; Chen, F.; Chu, Q.Q. Spatio-temporal variations of winter wheat water requirement and climatic causes in Huang-Huai-Hai Farming Region. Chin. J. Eco-Agric. 2012, 20, 356-362. (In Chinese) [CrossRef]

52. Yang, X.L.; Huang, J.; Chen, F.; Chu, Q.Q. Comparison of temporal and spatial variation of water requirement of corn in Huang-Huai-Hai farming system region. J. China Agric. Univ. 2011, 16, 26-31. (In Chinese)

(c) 2017 by the authors; licensee MDPI, Basel, Switzerland. This article is an open access article distributed under the terms and conditions of the Creative Commons Attribution (CC-BY) license (http://creativecommons.org/licenses/by/4.0/). 